УДК 343.8:343.26

DOI https://doi.org/10.51989/NUL.2021.6.32

\title{
ОБМЕЖЕННЯ ВОЛІ: ТРАНСФОРМАЦІЯ У ПРОБАЦІЙНИЙ КОНТРОЛЬ ТА ПРОБАЦІЙНИЙ НАГЛЯД
}

\section{Лисодєд Олександр Володимирович,}

кандидат юридичних наук, доцент, доцент кафедри кримінології та кримінально-виконавчого права Національного юридичного університету імені Ярослава Мудрого

У статті розглядається процес еволюції такого виду кримінального покарання, як обмеження волі, на теренах пострадянського простору. Зазначається, що вперше такий вид кримінального покарання з'явився у Російській Федерації (1996р.), потім - у Республіці Казахстан (1997р.) і полягав в триманні засудженого в спеціальній установі - виправному центрі без ізоляції від суспільства в умовах здійснення за ним нагляду.

Проте Російська Федерація на тривалий час відстрочила введення в дію цього виду кримінального покарання, у 2010 р. відмовилась від виконання цього виду покарання у виправних центрах, а обмеження волі стало полягати у встановленні судом тільки таких обмежень для засуджених: не виходити з дому в певний час доби; не відвідувати певні місця; не виїжджати за межі певної території; не відвідувати місця проведення масових та інших заходів і не брати участі у таких заходах; не змінювати місце проживання або перебування, місце роботи чи (або) навчання тощо.

у Республіці Казахстан у 2003 р. також було встановлено, що обмеження волі теж полягає у покладенні на засудженого судом відповідних обов'язків, що обмежують його свободу, і відбувається за місцем проживання під наглядом спеціалізованого органу без ізоляції від суспільства строком від одного до п'яти років. На сьогоднішній день обмеження волі у Казахстані полягає у встановленні пробаційного контролю за засудженим і притягненні його до примусової праці протягом усього терміну відбування покарання. Обмеження волі відбувається за місцем проживання засудженого без ізоляції від суспільства, його виконання покладено на службу пробації і поліцію.

Стверджується, що у Російській Федерації і Республіці Казахстан обмеження волі стало новим видом кримінального покарання, альтернативним покаранню у виді позбавлення волі.

В Україні ж виконання покарання у виді обмеження волі розпочалося з 2001 р. у виправних центрах в умовах здійснення за ними нагляду з обов'язковим залученням до праці. Акцентується увага на тому, що виправні центри сьогодні як установи виконання покарання територіально і організаційно не відрізняються від колоній мінімального рівня безпеки з полегшеними умовами тримання, а порядок і умови виконання і відбування кримінального покарання у виді обмеження волі у виправних центрах нічим не відрізняються від порядку і умов виконання покарання у виді позбавлення волі на певний строк у колоніях мінімального рівня безпеки з полегшеними умовами тримання. Зазначається, що обмеження волі не стало новим видом покарання, альтернативним позбавленню волі, оскільки порядок його виконання, передбачений у КВК України та підзаконних нормативно-правових актах, перетворив його на полегшений варіант позбавлення волі. У зв'язку з цим підтримується пропозиція Міністерства юстиції України щодо скасування обмеження волі як виду кримінального покарання і введення замість нього нового виду кримінального покарання - пробаційного нагляду.

Ключові слова: покарання, альтернативні позбавленню волі, обмеження волі, виправний центр, пробація, пробаційний контроль, пробаційний нагляд.

\section{Lysodyed Oleksandr. Restriction of freedom: transformation into probation control and probation supervision}

The article examines the evolution of this type of criminal punishment as restriction of freedom in the post-Soviet space. It is noted that for the first time this type of criminal punishment appeared in the Russian Federation (1996), then in the Republic of Kazakhstan (1997) and consisted in keeping the convicted person in a special institution - a correctional center without isolation from society in the conditions of its implementation. 
However, the Russian Federation for a long time postponed the introduction of this type of criminal punishment, in 2010 it refused to execute this type of punishment in correctional centers, and the restriction of freedom began to consist in the establishment of only subsequent restrictions by the court for convicted persons ... somehow: not to leave the house at a certain time of the day; do not visit certain places; do not travel outside a certain territory; not to visit places of mass and other events and take part in such events; not to change the place of residence or stay, place of work or (or) study.

In the Republic of Kazakhstan in 2003 it was also established that the restriction of freedom also consists in imposing on the convict by the court the corresponding duties restricting his freedom and takes place at the place of residence under the supervision of a specialized body without isolation from society for a period of one to five years. Today, restriction of freedom in Kazakhstan consists in establishing probationary control over a convict and bringing him to forced labor throughout the entire period of serving the sentence. Restriction of freedom occurs at the place of residence of the convict without isolation from society, its execution is entrusted to the probation service and the police.

It is argued that in the Russian Federation and the Republic of Kazakhstan, restriction of freedom was a new type of criminal punishment, alternative to the punishment of imprisonment.

In Ukraine, the execution of punishment in the form of restriction of freedom began in 2001 in correctional centers under conditions of supervision over them with mandatory involvement in labor. Attention is focused on the fact that today correctional centers as institutions for the execution of sentences do not differ geographically and organizationally from colonies with a minimum level of security with facilitated conditions of detention, and the procedure and conditions for the execution and serving of a criminal sentence in the form of restriction of freedom in correctional centers is no different from order. and the conditions for the execution of a sentence of imprisonment for a specified period in minimum security colonies with reduced conditions of detention. It is noted that restriction of freedom has not become a new type of punishment, alternative to imprisonment, since the procedure for its execution, provided for in the Penal code and by-laws, has turned it into a lighter version of imprisonment. However, the proposal of the Ministry of Justice of Ukraine is supported to abolish the restriction of freedom as a type of criminal punishment and to introduce instead a new type of criminal punishment probation supervision.

Key words: alternatives to imprisonment, restriction of freedom, correctional center, probation, probation control, probation supervision.

Обмеження волі як новий вид кримінального покарання на теренах пострадянського простору вперше з'явилось у Модельному КК СНД. У ньому обмеження волі знайшло своє місце між обмеженням по військовій службі та арештом і розумілось як тримання засудженого у колонії-поселенні без ізоляції від суспільства в умовах нагляду за ним строком від одного до п'яти років[1]. Певна частина пострадянських республік сприйняла такий вид кримінального покарання і майже дослівно продублювала у своїх нових кримінальних кодексах положення Модельного КК СНД, але надалі або скасували його, або вклали в цей вид покарання новий зміст.

Першою покарання у виді обмеження волі ввела Російська Федерація (1996 р.), потім - Республіка Казахстан (1997 р.), Республіка Білорусь (1999р.) і врештірешт Україна (2001р.). За ст. 53 КК РФ та ст. 45 КК РК обмеження волі полягало в триманні засудженого в спеціальній установі без ізоляції від суспільства в умовах здійснення за ним нагляду, за ст. 55 КК РБ - у триманні засудженого в умовах здійснення за ним нагляду з обов'язковим залученням до праці в місцях, визначених органами виконання покарань, за ст. 61 КК України - у триманні особи в кримінально-виконавчих установах відкритого типу без ізоляції від суспільства в умовах здійснення за нею нагляду з обов'язковим залученням засудженого до праці. У прийнятих пізніше кримінально-виконавчих кодексах установами для відбування покарання у виді обмеження волі були визначені виправні центри.

Проте і у Російській Федерації, і у Республіці Казахстан введення в дію цього виду покарання відстрочили. Так, змінами до федерального закону РФ про введення в дію КК РФ було встановлено, що положення КК РФ про покарання у виді обме- 
ження волі вводяться в дію федеральним законом після вступу в силу КВК РФ по мірі створення необхідних умов для виконання цього виду покарання, але не пізніше 2001 р. [2]. Потім цей строк був продовжений до 2005 р. [3], але реальне призначення покарання у виді обмеження волі та його виконання розпочалось з 2010 р. у зв'язку з прийняттям Федерального закону від 27.12.2009 р. № 377-Ф3 [4], який суттєво змінив зміст покарання у виді обмеження волі та порядок його виконання. Зокрема, за новою редакцією ч. 1 ст. 53 КК РФ обмеження волі полягало у встановленні судом таких обмежень для засуджених: не виходити з дому (квартири, іншого житла) в певний час доби; не відвідувати певні місця, що розташовані в межах території відповідного муніципального утворення; не виїжджати за межі території відповідного муніципального утворення; не відвідувати місця проведення масових та інших заходів і не брати участі у таких заходах; не змінювати місце проживання або перебування, місце роботи чи (або) навчання без згоди спеціалізованого державного органу, який здійснює нагляд за відбуванням засудженими покарання у виді обмеження волі. Частина 2 ст. 53 КК РФ встановлювала, що обмеження волі призначається на строк від двох місяців до чотирьох років в якості основного виду покарання за злочини невеликої тяжкості та злочини середньої тяжкості, а також на термін від шести місяців до двох років в якості додаткового виду покарання до примусових робіт або позбавлення волі у випадках, передбачених відповідними статтями Особливої частИнИ КК РФ.

КВК РФ з цього приводу був доповнений ст. $47^{1}$, в якій було зазначено, що спеціалізованим державним органом, який здійснює нагляд за відбуванням засудженими покарання у виді обмеження волі, $\epsilon$ кримінально-виконавча інспекція. Новелою російського законодавства у цій сфері стало те, що відповідно до ч. 1 ст. 60 КВК РФ для забезпечення нагляду, запобігання злочинам і з метою отримання інформації про поведінку засуджених кримінальновиконавчі інспекції отримали право використовувати аудіовізуальні, електронні та інші технічні засоби нагляду і конт- ролю, перелік яких був визначений Урядом Російської Федерації [5]. До переліку були включені персональні трекери (для носіння не більше 3 місяців), електронні браслети (для носіння більше 3 місяців), стаціонарні і мобільні пристрої для прийому їх сигналів, стаціонарні пристрої аудіовізуального контролю (для автоматичної візуальної і голосової ідентифікації засудженого), ретранслятори та інші технічні засоби та пристрої регіональних інформаційних центрів [6, с. 107-108]. Рішення про застосування технічних засобів нагляду і контролю було надано начальнику кримінально-виконавчої інспекції під час постановки засудженого на персональний облік, а також під час подальшого виконання покарання відповідно до положень Інструкції з організації виконання покарання у виді обмеження волі [7].

На момент введення покарання у виді обмеження волі на обліку у кримінальновиконавчих інспекціях Федеральної служби виконання покарань Росії перебувало 6,4 тис. осіб, у 2015 р. - вже 12,6 тис. осіб, у 2020 р. - вже 38,5 тис. осіб [8]. Сьогодні, відповідно до Концепції розвитку кримінально-виконавчої системи Російської Федерації на період до 2030 року, у РФ все ж таки планується до 2024 р. на базі кримінально-виконавчих інспекцій створити службу пробації [9]. 3 цього приводу в Громадській палаті РФ вже пройшли перші слухання по законопроєкту «Про систему пробації в Російській Федерації» [10], який підготувало Міністерство юстиції РФ [11]. Передбачається, що і інститут виконання покарання у виді обмеження зазнає чергових змін.

Законом про введення в дію КК Республіки Казахстан також було встановлено, що положення КК РК про покарання у виді обмеження волі вводяться після вступу в силу КВК РК по мірі створення необхідних умов для виконання цього виду покарання, але не пізніше 2003 р. [12]. На виконання цих положень, Законом Республіки Казахстан від 21.12.2002 р. № 363 були внесені відповідні зміни до КК РК та КВК РК [13]. Новою редакцією ст. 45 КК РК було встановлено, що обмеження волі полягає в покладенні на засудженого судом відповідних обов'язків, що обмеж- 
ують його свободу, і відбувається за місцем проживання під наглядом спеціалізованого органу без ізоляції від суспільства строком від одного до п'яти років. Суд, призначаючи покарання у виді обмеження волі, міг покласти на засудженого виконання таких обов'язків: не змінювати постійне місце проживання, роботи або навчання без повідомлення спеціалізованого органу; не відвідувати певні місця; у вільний від навчання і роботи час не покидати місце проживання; не виїздити в іншу місцевість без дозволу спеціалізованого органу. Суд міг покласти на засудженого до обмеження волі виконання й інших обов'язків, що повинні були сприяти його виправленню: пройти курс лікування від алкоголізму, наркоманії, токсикоманії, захворювань, що передаються статевим шляхом; здійснювати матеріальну підтримку сім'ї. Відповідно до змін у КВК РК особи, засуджені до обмеження волі, почали відбувати покарання у виді обмеження волі за місцем проживання за умови здійснення за ними нагляду кримінально-виконавчими інспекціями (ст. 43).

У 2014 р. у зв'язку з прийняттям нового КК РК зміст покарання у виді обмеження волі був знову змінений. Так, за початковою редакцією ст. 44 КК РК [14] обмеження волі стало полягати у встановленні пробаційного контролю за засудженим на строк від одного до семи років. Було встановлено, що обмеження волі відбувається за місцем проживання засудженого. Засуджені до обмеження волі, які не мали постійного місця роботи або не були зайняті навчанням, стали підлягати залученню до примусової праці у місцях, які визначали місцеві виконавчі органи, але не більше двохсот сорока годин на рік і до восьми годин на день, але не більше сорока годин на тиждень. Засуджені до обмеження волі неповнолітні, вагітні жінки, жінки, які мали малолітніх дітей у віці до трьох років, чоловіки, які виховували самотужки малолітніх дітей у віці до трьох років, жінки у віці п'ятдесяти восьми і більше років, чоловіки у віці шістдесяти трьох і більше років, інваліди першої або другої групи до примусової праці не залучались. У разі заміни іншого покарання обмеженням волі воно могло призначатись на строк менше одного року, при цьому засуджений до примусової праці не залучався.

Пробаційний контроль почав здійснюватися уповноваженим державним органом і за рішенням суду та включав виконання засудженим обов'язків: не змінювати постійного місця проживання, роботи, навчання без повідомлення уповноваженого державного органу, який здійснює контроль за поведінкою засудженого; не відвідувати певні місця; пройти курс лікування від алкоголізму, наркоманії, токсикоманії, захворювань, що передаються статевим шляхом; здійснювати матеріальну підтримку сім'ї; інші обов'язки, які сприяють виправленню засудженого і запобіганню вчинення ним нових кримінальних правопорушень.

у 2018 р., відповідно до Закону Республіки Казахстан від 12.07.2018 р. № 180VI [15], були внесені зміни у ст. 44 КК РК 2014 р., і на сьогоднішній день обмеження волі у Казахстані полягає у встановленні пробаційного контролю за засудженим на термін від шести місяців до семи років і притягненні його до примусової праці по сто годин щорічно протягом усього терміну відбування покарання. Обмеження волі відбувається за місцем проживання засудженого без ізоляції від суспільства. Примусова праця організовується місцевими виконавчими органами в громадських місцях і відбувається не більше як чотири години на день.

Додатково у 2020 р., згідно із Законом Республіки Казахстан від 07.07.2020 р. № 361-VI [16], обов'язок «пройти курс лікування від алкоголізму, наркоманії, токсикоманії, захворювань, що передаються статевим шляхом» був змінений на обов'язок «пройти курс лікування від психічних, поведінкових розладів (захворювань), пов'язаних із вживанням психоактивних речовин, захворювань, що передаються статевим шляхом».

Слід зазначити, що термін «пробаційний контроль» з'явився у законодавстві Казахстану ще у 2012 р. у зв'язку з запровадженням у кримінально-виконавчій системі Казахстану служби пробації. Так, відповідно до Закону Республіки Казахстан від 15.02.2012 р. № 556-IV [17] зміни були внесені у ч. 5-1 ст. 63 КК РК 1997 р., згідно з якими суд, призначаючи умовне 
засудження, встановлює пробаційний контроль і покладає на засудженого виконання певних обов'язків: не змінювати постійного місця проживання, роботи, навчання без повідомлення спеціалізованого державного органу, що здійснює контроль за поведінкою умовно засудженого; не відвідувати певні місця; пройти курс лікування від алкоголізму, наркоманії, токсикоманії, венеричного захворювання або ВІЛ/СНІД, здійснювати матеріальну підтримку сім'ї. Суд міг покласти на умовно засудженого виконання та інших обов'язків, які сприяють його виправленню. А згідно зі змінами до ст. 182 КВК РК 1998 р. пробаційний контроль вже розглядався як діяльність служби пробації кримінально-виконавчої інспекції щодо здійснення контролю за виконанням покладених судом на умовно засуджених обов'язків і їх поведінкою з наданням сприяння в отриманні соціально-правової допомоги в період випробувального терміну.

Сьогодні відповідно до ст. 5 Закону Республіки Казахстан від 30.12.2016 р. № 38-VI «Про пробацію» [18] пробаційний контроль розглядається як діяльність служби пробації і поліції щодо здійснення контролю за виконанням особами, які перебувають на їх обліку, обов'язків, покладених на них законом і судом. Згідно зі ст. 19 КВК РК 2014 р. [19] пробаційний контроль здійснюються щодо осіб: 1) засуджених до покарання у виді обмеження волі; 2) умовно засуджених; 3) звільнених умовно-достроково від відбування покарання у виді позбавлення волі. Для засуджених, які відбувають покарання у виді обмеження волі, ст. 66 КВК РК встановлює такі обов'язки: 1) виконувати призначені судом обов'язки; 2) виконувати вимоги служби пробації; 3) не відвідувати місця, визначені судом за поданням служби пробації; 4) не змінювати без повідомлення служби пробації місця проживання, роботи, навчання; 5) не виїжджати за межі адміністративно-територіальної одиниці без повідомлення служби пробації; 6) з'являтися в службу пробації в установлені дні для реєстрації і проведення з ними виховної роботи; 7) мати при собі документ, що засвідчує особу. Згідно зі ст. 69 КВК РК пробаційний контроль за засудженими, які відбувають покарання у виді обмеження волі, здійснюється службою пробації за місцем їх проживання відповідно до Правил організації діяльності служби пробації [20]. Для забезпечення належного контролю і отримання інформації про місце знаходження засудженого служба пробації теж, як і у Російській Федерації, має право використовувати електронні засоби стеження, перелік яких визначається Урядом Республіки Казахстан [21].

За даними голови Комітету кримінальновиконавчої системи МВС Республіки Казахстан Ж. Ешмагамбетова «тюремне населення» у країні за період 2010-2020 рр. скоротилась з 63 тис. до 30 тис., і Казахстан за ці роки перемістися у світовому рейтингу кількості ув'язнених з 31 на 100 місце, а кількість осіб, які підпадають під пробацію, збільшилась з 33 тис. до 60 тис. [22].

Таким чином, можна стверджувати, що у Російській Федерації і Республіці Казахстан обмеження волі стало новим видом кримінального покарання, альтернативним покаранню у виді позбавлення волі.

В Україні ж для реалізації положень КК України 2001 р. у виправні центри було перетворено певну частину наявних на той час колоній-поселень, які були побудовані ще за радянських часів за типовими проєктами для відбування покарання у виді позбавлення волі. На момент введення в дію КВК України, наказом Державного департаменту України з питань виконання покарань від 19.12.2003 р. № 251 [23] на території України було створено 16 виправних центрів, а надалі (станом на 01.11.2007 р.) їх кількість була доведена до 21 установи [24, с. 189]. За даними А. Геля, 18 з 21 виправного центру на момент створення мали статус виправнотрудових колоній-поселень, 2 - дільниць колоній-поселень при виправно-трудових колоніях різних видів режиму [25]. Будьяке інженерно-технічне переобладнання їх у виправні центри як у нові установи виконання покарань для виконання нового виду кримінальних покарань у подальшому так і не було здійснено. Надалі територіально і організаційно вони стали подібними колоніям мінімального рівня безпеки з полегшеними умовами тримання [26, с. 141], а порядок і умови виконання покарання у виді обмеження волі в них 
теж стали аналогічними порядку і умов виконання покарання у виді позбавлення волі у колоніях мінімального рівня безпеки з полегшеними умовами тримання [27, с. 105-136] з відповідною ізоляцією і наглядом.

Загалом обмеження волі не стало новим видом покарання, альтернативним позбавленню волі, як планували розробники КК України 2001 р., оскільки порядок його виконання, передбачений у КВК України та нормативно-правових актах Державного департаменту України з питань виконання покарань, перетворив його на полегшений варіант позбавлення волі [28, с. 156].

Проте на той час це повною мірою влаштовувало спочатку Державний департамент України з питань виконання покарань, а потім і Державну пенітенціарну службу України аж до моменту її ліквідації у 2016 р. та передачу їі повноважень в частині реалізації державної політики у сфері виконання кримінальних покарань Міністерству юстиції України. Витрати на утримання виправних центрів (підтримання інфраструктури, комунальні платежі, податки, заробітна плата штатних працівників та вільнонайманого персоналу, кошти на утримання засуджених та ін.) ніхто не рахував, доцільністю і ефективністю їх роботи ніхто не переймався.

У Міністерстві юстиції України все ж таки зрозуміли, що обмеження волі за порядком і умовами виконання нічим не відрізняється від позбавлення волі, а утримання виправних центрів (у 2017 р. їх нараховувалось 24 [29]) у сучасних умовах $є$ вкрай неефективним [30], оскільки кількість засуджених до обмеження волі в Україні останнім часом постійно зменшується (у 2012 р. до обмеження волі було засуджено найбільшу кількість осіб - 4640 осіб, у 2013 р. - 2671 особу, у 2014 p. 1876 осіб, у 2015 р. - 1504 особи, у 2016 р. - 1245 осіб, у 2017 p. 1099 осіб, у 2018 р. - 909 осіб, у 2019 р. 827 осіб [31, с. 64]), а витрати на утримання виправних центрів постійно збільшуються. Тому Міністерство юстиції України у процесі оптимізації діяльності слідчих ізоляторів, установ виконання покарань та підприємств установ виконання покарань, який розпочало з 2017 р., 12 виправних центрів вже законсервувало [32], а у 12 наявних виправних центрах станом на 06.08.2020 р. відбували покарання тільки 1382 засуджених [33], і їх утримання обійшлося у 2019 р. державному бюджету у 200 млн грн [34].

у зв'язку з цим Міністерство юстиції України розробило і вже направило до Верховної Ради України два законопроєкти щодо розвитку системи пробації, збільшення альтернатив позбавленню волі та створення умов для зниження рецидивної злочинності [35; 36], якими пропонує запровадити новий вид кримінального покарання - пробаційний нагляд, а обмеження волі як вид кримінального покарання скасувати.

Так, законопроєктом «Про внесення змін до Кримінального кодексу України, Кримінального процесуального кодексу України щодо розвитку системи пробації, збільшення альтернатив позбавленню волі та створення умов для зниження рецидивної злочинності» встановлюється:

1) пробаційний нагляд полягає в обмеженні прав і свобод засудженого, що спрямовані на його виправлення та запобігання вчиненню нових правопорушень, без ізоляції засудженого від суспільства;

2) пробаційний нагляд як основне покарання може застосовуватися на строк від одного до п'яти років. Пробаційний нагляд як додаткове покарання може застосовуватися на строк від одного до трьох років. Строк пробаційного нагляду, призначеного як додаткове покарання до покарання у виді штрафу, не може перевищувати одного року.

Пробаційний нагляд як додаткове покарання може бути призначений і у випадках, коли він не передбачений в санкції статті (санкції частини статті) Особливої частини КК, якщо суд, призначаючи основне покарання у виді громадських робіт, виправних робіт, штрафу або позбавлення права обіймати певні посади, або займатися певною діяльністю, дійде висновку про необхідність додаткового виправного впливу на засудженого;

3) пробаційний нагляд не призначається військовослужбовцям, а також у разі звільнення від відбування покарання з випробуванням; 
4) суд покладає на засудженого до пробаційного нагляду обов'язки: а) періодично з'являтися для реєстрації до уповноваженого органу з питань пробації, але не рідше одного разу на три місяці та не частіше чотирьох разів на місяць; б) повідомляти уповноважений орган з питань пробації про зміну свого місця проживання, роботи або навчання.

Суд може покласти на засудженого до пробаційного нагляду ще й такі обов'язки: а) пройти курс лікування від наркотичної, алкогольної залежності, розладів психіки та поведінки внаслідок вживання психоактивних речовин або захворювання, що становить небезпеку для здоров'я інших осіб; б) носити електронний засіб контролю та проживати за вказаною у рішенні суду адресою;

5) уповноважений орган 3 питань пробації може додатково покласти на засуджених такі обов'язки: а) не виїжджати за межі України без погодження з уповноваженим органом з питань пробації; б) працевлаштуватися або за направленням уповноваженого органу з питань пробації звернутися до органів державної служби зайнятості для реєстрації як безробітного та працевлаштуватися, якщо йому буде запропоновано посаду (роботу); в) виконувати заходи, передбачені пробаційною програмою; г) дотримуватися вимог щодо вчинення певних дій, пересування та проведення дозвілля, проживання за вказаною адресою; ґ) брати участь у складанні та реалізації заходів, передбачених індивідуальним планом соціально-виховної роботи із засудженим; д) пройти навчання, підготовку, перепідготовку чи підвищення кваліфікації;

6) обов'язки, які застосовуються до засудженого, мають бути необхідними для досягнення мети покарання.

Пробаційний нагляд як вид покарання пропонується передбачити у санкціях 250 статей Особливої частини чинного КК України.

Закопроєктом «Про внесення змін до деяких законодавчих актів щодо розвитку системи пробації, збільшення альтернатив позбавленню волі та створення умов для зниження рецидивної злочинності» пропонується:

1) у ст. 11 такий вид установ виконання покарань, як «виправні центри», виклю- чити, поділ установ виконання покарань на «кримінально-виконавчі установи відкритого типу» та «кримінально-виконавчого типу» скасувати;

2) главу 13 КВК України (статті 56-70), яка регулює виконання покарання у виді обмеження волі, виключити;

3) доповнити КВК України главою $5^{1}$ «Виконання покарання у виді пробаційого нагляду», в якій закріпити такі положення:

а) виконання покарання у виді пробаційного нагляду покладається на уповноважені органи з питань пробації;

б) уповноважений орган з питань пробації: 1) веде облік засуджених до покарання у виді пробаційного нагляду; 2) роз'яснює засудженим порядок та умови відбування покарання; 3) здійснює контроль за додержанням засудженими порядку та умов відбування покарання; 4) визначає, які додаткові обов'язки необхідно покласти на засудженого, контролює виконання таких обов'язків, приймає рішення про їх заміну чи скасування за результатами оцінки криміногенного ризику; 5) проводить оцінку криміногенного ризику; 6) визначає порядок та періодичність явки на реєстрацію; 7) контролює виконання обов'язків, покладених на засудженого судом, звертається до суду з поданням про зміну покладених обов'язків за результатами оцінки криміногенного ризику; 8) за заявою засудженого звертається до суду з поданням про зміну визначеної у рішенні суду адреси місця відбування покарання; 9) застосовує заходи заохочення; 10) вживає першочергових заходів з виявлення засуджених, місцезнаходження яких невідоме; 11) звертається до відповідних правоохоронних органів щодо розшуку засуджених, місцезнаходження яких невідоме;

в) засуджені до покарання у виді пробаційного нагляду зобов'язані: 1) додержуватися встановлених відповідно до закону порядку та умов відбування покарання; 2) виконувати покладені на них обов'язки; 3) повідомляти уповноважений орган з питань пробації про зміну місця проживання, роботи або навчання; 4) з'являтися для реєстрації до уповноваженого органу з питань пробації; 5) з'являтися за викликом до уповноваженого органу з питань пробації у порядку та з періодичністю, 
встановленою уповноваженим органом з питань пробації;

г) порядок застосування електронних засобів контролю та нагляду за поведінкою осіб, на яких покладено цей обов'язок, затверджується Міністерством юстиції України.

У разі прийняття Верховною Радою України вказаних законопроєктів службу пробації чекає досить велика за обсягом робота щодо запровадження пробаційного нагляду, але якраз цю ініціативу Міністерства юстиції України слід підтримати, бо саме таке розуміння обмеження прав і свобод людини та громадянина на рівні кримінального закону цілком відповідає рекомендаціям Комітету Міністрів Ради Європи CM/Rec (2010) 1 про пробації, CM/Rec (2014) 4 стосовно електронного моніторингу, CM/Rec (2017) 3 про Європейські правила щодо громадських санкцій та заходів.

\section{ЛITЕРАТУРА:}

1. Модельный Уголовный кодекс (рекомендательный законодательный акт для Содружества Независимых Государств): принят Межпарламентской Ассамблеей государств-участников Содружества Независимых Государств постановлением от 17.02.1996 г. URL: https:// docs.cntd.ru/document/901781490 (дата звернення: 07.11.2021).

2. О внесении изменений и дополнений в Федеральный закон «О введении в действие Уголовного кодекса Российской Федерации» : Федеральный закон от 27.12.1996 г. № 161-Ф3. URL: https://docs.cntd.ru/document/9034642 (дата звернення: 07.11.2021).

3. О внесении изменений и дополнений в федеральные законы «О введении в действие Уголовного кодекса Российской Федерации» и «О введении в действие Уголовно-исполнительного кодекса Российской Федерации»: Федеральный закон от 10.01.2002 г. № 4-Ф3. URL: https://docs.cntd.ru/document/901808294 (дата звернення: 07.11.2021).

4. О внесении изменений в отдельные законодательные акты Российской Федерации в связи с введением в действие положений Уголовного кодекса Российской Федерации и Уголовно-исполнительного кодекса Российской Федерации о наказании наказания в виде ограничения свободы: Федеральный закон от 27.12.2009 г. № 377-Ф3. URL: https://docs.cntd.ru/ document/902192493 (дата звернення: 07.11.2021).

5. Перечень аудиовизуальных, электронных и иных технических средств надзора и контроля, используемых уголовно-исполнительными инспекциями для обеспечения надзора за осужденными к наказанию в виде ограничения свободы: утв. постановлением Правительства Российской Федерации от 31.03.2010 г. № 198. URL: http://www.consultant.ru/ document/cons_doc_LAW_99050/8d2803ce78bbd05ed3ce777af492271f9f607f5c/ (дата звернення: 07.11.2021).

6. Романова С.В. Практика применения электронных браслетов: история и современность. Научно-методический электронный журнал «Концепт». 2015. № 2 (февраль). С. 106-110. URL: http://e-koncept.ru/2015/15046.htm (дата звернення: 07.11.2021).

7. Инструкция по организации исполнения наказания в виде органичения свободы: утв. приказом Министерства юстиции Российской Федерации от 11.10.2010 г. № 258. URL: https://docs.cntd.ru/document/902241633 (дата звернення: 07.11.2021).

8. Характеристика лиц, состоящих на учете в уголовно-исполнительных инспекциях. URL: https://fsin.gov.ru/structure/inspector/iao/statistika/Xar-ka\%20v\%20YII/ (дата звернення: 07.11.2021).

9. Концепция развития уголовно-исполнительной системы Росийской Федерации до 2030 года: утв. распоряжением Правительства Российской Федерации от 29.04.2021 г. № 1138-p. URL: http://www.consultant.ru/document/cons_doc_LAW_383610/7eada0efe8cc5c 372459d10f592b9da02b0b877d/ (дата звернення: 07.11.2021).

10. Трифонова Е. После тюрьмы жизнь только начинается. URL: https://www.ng.ru/ politics/2021-07-12/3_8196_life.html (дата звернення: 07.11.2021).

11. Куликов В. Научат жить вольно. Новая служба поможет бывшим заключенным на свободе. URL: https://rg.ru/2021/01/19/novaia-sluzhba-probacii-pomozhet-byvshimzakliuchennym-na-svobode.html (дата звернення: 07.11.2021).

12. О введении в действие Уголовного кодекса Республики Казахстан: Закон Республики Казахстан от 16 июля 1997 г. №168-I. URL: https://online.zakon.kz/Document/?doc_ 
id=1008032\&doc_id2=1008037\# activate_doc=2\&pos=9;-82\&pos2=13;-84 (дата звернення: 07.11.2021).

13. О внесении изменений и дополнений в Уголовный, Уголовно-процессуальный и Уголовно-исполнительный кодексы Республики Казахстан: Закон Республики Казахстан от 21.12.2002 г. № 363. URL: https://adilet.zan.kz/rus/docs/Z020000363_ (дата звернення: $07.11 .2021)$.

14. Уголовный кодекс Республики Казахстан: Кодекс Республики Казахстан от 03.07.2014 г. № 226-V. URL: https://online.zakon.kz/Document/?doc_id=31575252\&doc_ id2=39772692 \#activate_doc=2\&pos=4;-82\&pos2=845;-21 (дата звернення: 07.11.2021).

15. О внесении изменений и дополнений в некоторые законодательные акты Республики Казахстан по вопросам совершенствования уголовного, уголовно-процессуального законодательства и деятельности правоохранительных и специальных государственных органов: Закон Республики Казахстан от 12.07.2018 г. № 180-VI. URL: https://online.zakon.kz/ Document/?doc_id=34803153\#pos=1;-16 (дата звернення: 07.11.2021).

16. О внесении изменений и дополнений в некоторые законодательные акты Республики Казахстан по вопросам здравоохранения: Закон Республики Казахстан от 07.07.2020 г. № 361-VI. URL: https://adilet.zan.kz/rus/docs/Z2000000361 (дата звернення: 07.11.2021).

17. О внесении изменений и дополнений в некоторые акты Республики Казахстан по вопросам службы пробации: Закон Республики Казахстан от 15.02.2012 г. № 556-IV. URL: https://adilet.zan.kz/rus/docs/Z1200000556 (дата звернення: 07.11.2021).

18. О пробации: Закон Республики Казахстан от 30.12.2016 г. № 38-VI. URL: https:// online.zakon.kz/Document/?doc_id=36232217 (дата звернення: 07.11.2021).

19. Уголовно-исполнительный кодекс Республики Казахстан: Кодекс Республики Казахстан от 05.07.2014 г. № 234-V. URL: https://adilet.zan.kz/rus/docs/K1400000234/k140234. htm (дата звернення: 07.11.2021).

20. Правила организации деятельности службы пробации: утв. приказом Министра внутренних дел Республики Казахстан от 14.08.2014 г. № 511. URL: https://adilet.zan.kz/rus/ docs/V14C0009738 (дата звернення: 07.11.2021).

21. Перечень электронных средств слежения, используемых службой пробации уголовноисполнительной системы и сотрудниками полиции органов внутренних дел Республики Казахстан: утв. постановлением Правительства Республики Казахстан от 07.11.2014 г. № 1180. URL: https://zakon.uchet.kz/rus/docs/P1400001180 (дата звернення: 07.11.2021).

22. Количество заключенных сократилось в два раза в PK. URL: https://forbes.kz/ news/2020/11/23/newsid_238267 (дата звернення: 07.11.2021).

23. Перелік установ кримінально-виконавчої системи, які виконують покарання у виді арешту, обмеження волі, позбавлення волі на певний строк, довічного позбавлення волі. Київ, 2003. 27 с.

24. Науково-практичний коментар Кримінально-виконавчого кодексу України / А.П. Гель, О.Г. Колб, В.О. Корчинський та ін. ; за заг. ред. А.Х. Степанюка. Київ : Юрінком Інтер, 2008. 496 c.

25. Гель А. Чи можна вважати покарання у виді обмеження волі реальною альтернативою позбавленню волі на певний строк. URL: https://khpg.org/1239797977 (дата звернення: 07.11.2021).

26. Лисодєд О.В. Обмеження волі, арешт та пенітенціарний пробаційний арешт. Науковий вісник Міжнародного гуманітарного університету. Серія: Юриспруденція. 2021. № 49. С. $140-144$.

27. Остапко К.С. Правова регламентація виконання покарання у виді позбавлення волі у колоніях мінімального рівня безпеки: дис. ... канд. юрид. наук. Харків, 2018. 195 с.

28. Лисодєд О.В. Еволюція виконання покарання у виді обмеження волі на пострадянському просторі. Питання боротьби зі злочинністю. Харків : Право, 2012. Вип. 23. С. 145-157.

29. Перелік найменувань органів, установ виконання покарань, слідчих ізоляторів Державної кримінально-виконавчої служби України: затв. наказом Міністерства юстиції України від 10.05.2017 р. № 1519/5. URL: https://ips.ligazakon.net/document/MUS29030 (дата звернення: 07.11.2021). 
30. Денис Малюська бажає, щоб всі засуджені мали план відбування покарання, та розширює застосування застави та пробації. URL: https://sud.ua/ru/news/publication/188207-denismalyuska-bazhaye-schob-vsi-zasudzheni-mali-plan-vidbuvannya-pokarannya-ta-rozshiryayezastosuvannya-zastavi-ta-probatsiyi (дата звернення: 07.11.2021).

31. В'юник М.В., Карчевський М.В., Арланова О.Д. Кримінально-правове регулювання в Україні: реалії та перспективи (аналітичні матеріали) ; упоряд. Ю.В. Баулін. Харків : Право, 2020. 212 c.

32. Загальна характеристика Державної кримінально-виконавчої служби України. URL: https://kvs.gov.ua/ wp-content/uploads/2021/08/Загальна-характеристика-01.08.2021.pdf (дата звернення: 07.11.2021).

33. Малюська пропонує «підкорегувати» Кримінальний кодекс і закрити 12 виправних центрів. URL: https://www.ukrinform.ua/rubric-society/3076928-maluska-proponue-pidkoreguvatikriminalnij-kodeks-i-zakriti-12-vipravnih-centriv.html (дата звернення: 07.11.2021).

34. Утримання 12 виправних центрів торік обійшлося державі майже у 200 мільйонів. URL: https://www.ukrinform.ua/rubric-society/3098110-utrimanna-12-vipravnih-centriv-torikobijslosa-derzavi-majze-u-200-miljoniv.html (дата звернення: 07.11.2021).

35. Проект Закону про внесення змін до деяких законодавчих актів щодо розвитку системи пробації, збільшення альтернатив позбавленню волі та створення умов для зниження рецидивної злочинності від 12.04.2021 р. № 5359. URL: http://w1.c1.rada.gov.ua/pls/zweb2/ webproc4_1?pf3511=71628 (дата звернення: 07.11.2021).

36. Проект Закону про внесення змін до Кримінального кодексу України, Кримінального процесуального кодексу України щодо розвитку системи пробації, збільшення альтернатив позбавленню волі та створення умов для зниження рецидивної злочинності від 12.04.2021 p. № 5360. URL: http://w1.c1.rada.gov.ua/pls/zweb2/webproc4_1?pf3511=71629 (дата звернення: 07.11.2021). 